УДК 343.9.01

DOI https://doi.org/10.32849/2663-5313/2020.7.54

\title{
Мар'яна Флюнт,
}

аспірантка кафедри кримінологї та кримінально-виконавчого права

Національного університету «Одеська юридична академія»

\section{ТЕОРЕТИКО-МЕТОДОЛОГІЧНІ ОСНОВИ ВИВЧЕННЯ СПОСОБУ ВЧИНЕННЯ ЗЛОЧИНУ У КРИМІНОЛОГІЧНІЙ НАУЦІ}

Статтю присвячено дослідженню теоретико-методологічних основ вивчення способу вчинення злочину у кримінологічній науиі. Зазначено, що спосіб вчинення злочину є міжгалузевою категорією для наук кримінального ииклу, розглядається як складник механізму злочинної поведінки або елемент об’єктивної сторони складу злочину.

Вказано, що з-поміж усіх наук кримінального ииклу спосіб вчинення злочину є найменш вивченим у вітчизняній кримінології, оскільки дослідження способу вчинення злочину здійснювалися поверхнево та «фрагментарно», здебільшого як підрозділ дисертащійного дослідження чи публікація, що мають «формальний характер», але не заглиблюються в суть способу, його детермінаиію.

У роботі визначено окремі проблеми та труднощі кримінологічного розуміння поняття «спосіб вчинення злочину», зазначено про можливості застосування у вітчизняній кримінологї теоретичних і методологічних основ вивчення “тоdus орегаndi”, описано деякі перспективи здійснення досліджень у зазначеній сфері та розроблення кримінологічної кониепиії способу вчинення злочину.

Наголошено, що відмова від повноцінного кримінологічного вивчення способу вчинення злочину зумовлює існування значних прогалин у загальній картині злочинності та профілі особи злочиния, неврахування спечифічних для кожного окремого виду злочинності об'єктивних та суб'єктивних детермінант, неможливість формування ефективної моделі попередження та протидії злочинам тощо.

Висловлено думку про те, що кримінологічне дослідження способу вчинення злочину матиме не лише науково-теоретичну иінність, а й практичну значущість, оскільки дозволить виявляти недоліки та вразливості об'єктів злочинних посягань, розширить можливості застосування кримінологічного моделювання, а також буде актуальним у плануванні та при формуванні кримінальної політики держави

Автор зазначає, що формування рекомендаиій, розроблення методики та стратегї дослідження способів вчинення злочинів є ключовими напрямами для сучасного вивчення злочинності для подальшого формування кониепиї кримінологічного дослідження способу вчинення злочину, а також наповнення ї̈ змістом, визначення структури та категорійного апарату. Зазначеним сферам будуть присвячені і подальші дослідження автора.

Ключові слова: злочинний умисел, злочинна поведінка, механізм вчинення злочину, modus operandi, детермінація способу вчинення злочину, кримінологічна концепція.

Постановка проблеми. Спосіб вчинення злочину є однією з ключових категорій у криміналістиці (як сукупність дій з підготовки, вчинення та приховування злочину; як механізм вчинення злочину), у теорії кримінального права (як один з елементів об'єктивної сторони складу злочину), в кримінальнопроцесуальній теорії доказування (як одна з обставин, що підлягає доказуванню у кримінальному провадженні).

У кримінології способу вчинення злочину приділяється незначна увага, оскільки останній здебільшого розглядається лише в контексті дослідження механізму злочинної діяльності. Прийнято вважати, що спосіб вчинення злочину - центральна ланка харак- теристики діяння, а всі інші елементи так чи інакше пов'язані зі способом, хоча і мають самостійне значення [1, с. 79].

Окремі науковці [2, с. 143] зазначають, що у кримінології спосіб вчинення злочину розглядається не просто як елемент механізму злочинної поведінки, а як його частина - планування злочину. Так, на думку Г.Г. Шіханцова, планування, як складник злочинної поведінки, залежить від особистості злочинця, поточної обстановки i включає три елементи (вибір мети, вибір об'єкта посягання і визначення засобів досягнення мети), а способом вчинення злочину варто вважати «сукупність прийомів, що використовуються злочинцем при реалізації своїх намірів» [3]. 
Проблематичним є й те, що «спосіб вчинення злочину» та «механізм злочинної поведінки» часто ототожнюють. Помилкове ототожнення також здійснюється щодо кримінологічного розуміння механізму вчинення злочину та криміналістичного розуміння того ж поняття. Крім того, механізм вчинення злочину часто суто інстинктивно відносять виключно до сфери криміналістичних досліджень, що значно обмежує можливості вивчення цієї категорії науковцями та створює плутанину в розумінні для читачів і зацікавлених осіб.

Відмова від повноцінного кримінологічного вивчення способу вчинення злочину зумовлює існування значних прогалин у загальній картині злочинності та профілі особи злочинця, неврахування специфічних для кожного окремого виду злочинності об'єктивних і суб'єктивних детермінант зумовлює неможливість формування ефективної моделі попередження та протидії злочинам, ведення недієвої в реальних обставинах кримінальної політики тощо.

Я повністю погоджуюся 3 тезою, що «назріло питання про необхідність у деякому сенсі «переформатувати» класичне визначення питання про предметну приналежність інституту способу вчинення злочину» [1, с. 79]. Саме тому формуванню та дослідженню кримінологічного вчення про спосіб вчинення злочину, розробці в його межах змісту, структури та чіткого понятійного апарату будуть присвячені мої подальші роботи

Аналіз останніх досліджень і публікацій. Аналізуючи сучасний стан наукового дослідження способу вчинення злочину як окремого інституту в кримінології та в інших науках кримінального циклу, насамперед варто ознайомитися з авторами фундаментальних робіт щодо механізму вчинення злочину, оскільки спосіб є складовим елементом механізму. Таким чином, наукові дослідження механізму злочинної поведінки є вихідними для концептуальних досліджень способу вчинення злочину як самостійного об'єкту наукового пізнання.

Комплексне дослідження історії виникнення і розвитку вчень про механізм вчинення злочину було здійснено А.В. Самойловим. Так, за А.В. Самойловим, першими криміналістичними дослідженнями механізму вчинення злочину були роботи А.Н. Васильєва та Р.С. Бєлкіна, крім того зазначена категорія згадувалася у роботах Г.Ю. Маннса, Б.М. Шавера, Г.Г. Зуйкова, C.I. Новікова; фундаментальними дослідженнями механізму вчинення злочину у кримінально-правовому та кримінологічному аспектах були роботи Г.А. Аванесова,
Ю.М. Антоняна, В.К. Глістіна, П.С. Дагеля, H.I. Коржанского, В.М. Кудрявцева, Г.М. Міньковського, Н.І. Панова, А.А. Піонтковского [4], О.М. Бандурки, О.М. Литвинова, С.М. Блажівського та інших.

Особливої уваги заслуговує дослідження 1981 року за авторства Ю.М. Антоняна, Н.А.Барановського,П.С.Дагеля,О.Л.Дубовика, В.Н. Кудрявцева, Б.Я. Петеліна та Т.Г. Шавгулідзе. Крім того, механізму злочинної діяльності як міждисциплінарній науковій категорії було присвячено роботу А.Ф. Лубіна.

Дослідження способу вчинення злочину як міждисциплінарної / кримінально-правової / криміналістичної / кримінологічної категорії було здійснено у публікаціях як вітчизняних, так і зарубіжних науковців. Спосіб вчинення злочину як міждисциплінарна категорія розглядається, зокрема, у роботах М.I. Панова та Б. Щура «Про вивчення способу вчинення злочину в науках кримінального циклу: міждисциплінарний підхід», С.I. Коновалова та О.В. Айвазової «Міждисциплінарний характер категорії «спосіб вчинення злочину»: проблема співвідношення кримінально-правових, кримінально-процесуальних і криміналістичних аспектів», C.I. Коновалова «Спосіб злочину: кримінально-правові, кримінально-процесуальні і криміналістичні аспекти», В.І. Резюка «Кримінально-правовий, криміналістичний і кримінологічний аспекти способу вчинення злочину: уніфікація та відокремлення».

Дослідження способу вчинення злочину як категорії кримінально-правової сфери були здійснені у роботах М.I. Панова, Ю.В. Ніколаєва, Е.А. Рогачкіної, В. Федишиної, М.А. Атальянц, С.В. Шиловського та інших. Щодо виключно криміналістичних досліджень способу вчинення злочину, то окремі питання було розглянуто у роботах А.Л. Дуднікова, І. Гори, Б.В. Боріна, Д.В. Бочкіна, С.В. Пахомова та інших.

Натепер у вітчизняній науці немає єдиного комплексного кримінологічного вчення про спосіб вчинення злочину, хоча останній почав розглядатися в кримінологічному аспекті ще в 70-х рp. XX ст. За весь цей час спосіб вчинення злочину не отримав належної уваги та розвитку як інститут у кримінології і навіть як окреме поняття.

Дослідження способу вчинення злочину здійснювалися та здійснюються поверхнево, несистематично та «фрагментарно», зазвичай як підрозділ дисертаційного дослідження чи публікація, що мають такий собі «формальний характер» та не заглиблюються в суть вивчення способу, його детермінації. Так, Т.А. Стельмах є автором публікації «Кримінологічна характеристика способів 
вчинення вбивства», В.І. Гладких - «Кримінологічна характеристика найбільш поширених способів вчинення злочинів у сфері кредитування».

Вважаю за необхідне також зазначити, що у своїх роботах закордонні науковці (найчастіше представники англо-американської правової сім'ї) для опису способу вчинення злочину використовують поняття "modus operandi” (з лат. «образ дії»), що є основою для складення психологічного профілю злочинця, так званого «профілювання». Одними $з$ перших робіт у цій сфері можна назвати дослідження Major Lewellyn W. Atcherley "Modus Operandi: Criminal Investigation and Detection" (1913 р.) та Raymond B. Fosdick "Modus Operandi System in the Detection of Criminals" (1916 р.). Крім того, modus operandi може бути використаний як доказ вини злочинця [5].

Прикладами сучасного застосування modus operandi для дослідження та створення профілю особистості злочинця $\epsilon$, зокрема, роботи Stephen W. Smallbone, Richard Wortley "Child Sexual Abuse: Offender Characteristics and Modus Operandi (Trends \& issues in crime and criminal justice) Unknown Binding - 1” (2001 p.), Benoit Leclerc, Jean Proulx, Patrick Lussier, JeanFrancois Allaire "Offender - victim interaction and crime event outcomes: modus operandi and victim effects on the risk of intrusive sexual offenses against children" (2009 p.), Jonathan James, Jean Proulx "The modus operandi of serial and nonserial sexual murderers: A systematic review' (2016 p.), Eric Beauregard "Modus Operandi of Sex Offenders" (2018 p.), Balsing Khandusing Rajput "Understanding modus operandi of the cyber economic crime from people-process-technology framework's perspective" (2018 p.), Yu-Sheng Li, MingLiang Qi "An approach for understanding offender modus operandi to detect serial robbery crimes" (2019 p.), Nuria LorenzoDus, Anina Kinzel, Matteo Di Cristofaro "The communicative modus operandi of online child sexual groomers: Recurring patterns in their language use" (2020 p.), Tim Ayling "Modus operandi and cyberprofiling" (2020 р.) тощо.

Таким чином, у нашому науковому сприйнятті modus operandi $є$ трохи обмеженим порівняно 3 традиційними підходами до дослідження способу вчинення злочину у будь-якій науці кримінального циклу, адже modus operandi зводиться до вивчення образу дії злочинця та створення його подальшого профілю, що є лише окремим складником предмету кримінології - вивчення особистості злочинця. Вважаю, що теоретичні та методологічні основи дослідження modus operandi можуть та повинні бути використані при розробленні концепції кримінологічного дослідження способу вчинення злочину.

Метою статті $€$ аналіз сучасних теоретико-методологічних основ вивчення способу вчинення злочинів у кримінологічній науці, а також визначення напрямів і перспектив формування кримінологічної концепції способу вчинення злочину.

Виклад основного матеріалу. Злочинність та інші форми девіантної поведінки людини завжди викликали значний інтерес та резонанс у суспільстві, були об'єктами досліджень і суперечок науковців різних галузей, однак комплексною наукою, яка вивчає такий напрям діяльності, є саме кримінологія, що опирається на правові, соціологічні, психологічні знання та досягнення інших вчень про суспільство і людину.

Кримінологи спільно 3 колегами 3 різних сфер науки здійснюють значний внесок у розв'язання соціальних проблем, розроблення алгоритмів спільних дій, спрямованих на покращення загального соціального клімату, зниження ризиків, нейтралізацію криміногенних факторів і припинення злочинних виявів. Як зазначає В.М. Бурлаков, «основною функцією кримінології є аналіз кримінальних явищ і своєчасний діагноз для подальшої роботи 3 «оздоровлення» соціуму. Саме таким чином кримінологія може реалізуватися як «наука управління кримінальними процесами у суспільстві» [6, с. 237].

Актуальною є позиція В.П. Шієнока, на думку якого в науках кримінального циклу кримінологічна методологія $є$ фундаментальною і основоположною [7, с. 89-90], та М.С. Рибака, який зазначав, що пріоритетним правом у дослідженні соціальної дійсності користується кримінологія як самостійна наука, що вивчає злочинність, їі причини та умови, а також розробляє заходи запобігання злочинності [8].

3 моменту свого зародження кримінологія пройшла величезний шлях пізнання кримінальних реалій і їх закономірностей. Вітчизняними та закордонними кримінологами створені грунтовні теоретичні моделі та концепції [9, с. 30], проведено значні кримінологічні дослідження та вдосконалено методологічні основи їх здійснення Однак в сучасних умовах стрімкого розвитку та реформації суспільства, зміни ідеології та ціннісних орієнтирів особистості, вдосконалення технологій, а також накопичення масиву знань у науках кримінального циклу виникає необхідність у модернізації концептуальних і теоретичних основ кримінології, застосування інтеграційного підходу до аналізу і узагальнення даних. 
Останніми роками окремі питання, концепції та подальші перспективи науки кримінології неодноразово були предметом комплексних досліджень та темою активного дискурсу науковців-кримінологів Так, одним із фундаментальних досліджень є робота професора В.М. Дрьоміна «Інституціональна теорія злочинності та криміналізації суспільства» (2010), присвячена концепції, яка розкриває механізм криміналізації сучасного українського суспільства і сутність злочинності з позицій інституціоналізму як міждисциплінарної методологічної теорії.

У зазначеній роботі автором сформована інституціональна концепція криміналізації суспільства, в основі якої лежать два взаємопов'язані глобальні процеси: криміналізація соціальних інститутів та інституціоналізація кримінальних практик; а також розкрито зміст і методологічне значення інституціональної теорії криміналізації суспільства, сформульовано iï концептуальні основи тощо [10].

Окремої уваги також заслуговують публікації Я.І. Гілінського «Кримінологія сьогодні: досягнення, проблеми, перспективи» (2010), Ю.М. Антоняна «Кримінологія майбутнього: міждисциплінарні наукові зв'язки» (2014), В.В. Голіни «Сучасна кримінологія: досягнення, проблеми, перспективи» (2016), Д.А. Шестакова «Чого я чекаю від кримінології вже завтра» (2016), В.О. Тулякова "Neo criminology" (2016), T.А. Денисової «Кримінологія сьогодення. Кримінологія майбутнього» (2016), Т.В. Мельничук «Постмодерністська парадигма кримінології» (2016), В.М. Дрьоміна «Сучасні функції кримінології (2017), «Чи існує в Україні державна кримінологічна політика?» (2018), В.М. Фадєєва «Розвиток кримінології майбутнього» (2018).

Кримінологія не є статичною. Це наука, яка постійно перебуває у розвитку, реагує на зміни та сучасні виклики. Саме тому кримінологи поступово розширюють сферу інтересів та напрями своїх досліджень, застосовують нові методи їх здійснення, висловлюють власні концептуальні ідеї та вдосконалюють термінологію, що відкриває нові горизонти наукового знання та збагачує кримінологію новим змістом.

Як було зазначено, необхідно якнайшвидше модернізувати окремі концептуальні та теоретичні основи фундаментальної кримінології. Одним із перспективних, однак мало досліджуваних напрямів, що потребує самостійного вивчення та вдосконалення, $€$ кримінологічне дослідження способів вчинення злочинів. Таке дослідження повинно опиратися на матеріали слідчої та судової практики (так звані реальні «кейси»), бути обгрунтованим і змістовним, розглядати спосіб не лише як складник механізму вчинення злочину, а й як окремий об'єкт кримінологічного дослідження, здатний змінити наявні кліше щодо окремих видів злочинів і злочинності загалом.

Спосіб властивий будь-якому свідомому вибору і вольовій поведінці людини. Кожен злочинець також має свою систему прийомів, методів, спрямованих на досягнення мети злочинного діяння, зумовлених об'єктивними і суб'єктивними ознаками (обстановкою, функціональними можливостями, моральними установками) [2, с. 142].

Кожна наука аналізує спосіб вчинення злочину, виходячи 3 власних інтересів, проблематики, завдань і предмету. Кримінальне право розглядає спосіб вчинення злочину в усіченому вигляді (виділяються виключно юридично значимі ознаки), криміналістика - в повному (можуть виділятися всі можливі матеріальні і ідеальні ознаки), кримінологія - навіть у розширеному (при оцінці ще не реалізованого злочинного задуму, тобто явища, яке, можливо, реальним не стане) стосовно терміну «спосіб» [2, c. 146-147].

Як стверджують науковці [2, 11], для всіх наук кримінального циклу спільними є низка основних проблем щодо способу вчинення злочину, які заслуговують «генералізації» з метою поглибленого наукового аналізу:

- проблеми загального поняття способу вчинення злочину та відсутність єдиного погляду на його зміст у взаємопов'язаних науках (у кримінальному праві, криміналістиці, кримінології),

- недостатня увага, присвячена питанням детермінованості способів вчинення злочинів,

- відсутність спільних підходів до класифікації способів вчинення злочинів, до поняття їх основних видів (типів) тощо.

M.I. Панов зазначає, що обсяг і межі вивчення названих «загальних» проблем способу для кожної з наук, як і значення висновків кожної з них для інших (суміжних) галузей знання, не однакові. Це зумовлено тим, що зазначені науки, перебуваючи у тісному зв'язку, по-різному співвідносяться між собою. Ця обставина є наслідком того, що одні з наук є з точки зору їх співвідношення фундаментальними, інші ж - прикладними [11, с. 539].

Як відомо, кримінологія є теоретикоприкладною наукою, покликанням якої є, зокрема, комплексне дослідження злочинності, девіантності, криміногенності загалом та їх окремих виявів. Таким чином, кримі- 
нологічне дослідження способів вчинення злочинів є необхідним і ключовим, адже не можливо об'єктивно та якісно описати певне явище, не заглиблюючись і не вивчаючи його внутрішні взаємодії, закономірності та тенденції.

Отже, якими є бачення теоретичного і практичного значення способу вчинення злочину в сучасних кримінологічних дослідженнях? Розгляньмо позиції окремих науковців. Так. кримінологія розглядає спосіб для з'ясування кримінологічної характеристики злочинів, аналізу стану, динаміки окремих видів злочинів, встановлення причин і умов, що сприяють їх вчиненню, для розробки заходів запобігання злочинам [12, с. $6-8]$.

На думку В.І. Резюка, кримінологічний аспект способу вчинення злочину, що, зокрема, характеризує безпосередньо злочинне діяння, може включати як елементи, відображені в окремих кримінально-правових конструкціях (складах злочину), i обмежуватись лише ними, так і іх комплекс, що дозволить більш точно охарактеризувати структуру злочинності; виділити додаткові дані про особу злочинця, його потенціал, професію та інші відомості, які не мають кримінально-правового та криміналістичного значення; визначити ставлення злочинця до об'єкта і предмету посягання; встановити реальні причини злочинів, основні об'єктивні та суб'єктивні детермінанти способу вчинення злочину; оцінити ймовірність застосування окремого способу вчинення злочину i, виходячи з практики, частоту його застосування; визначити віктимність об'єкта посягання; виявити та розкрити недоліки всього комплексу заходів із протидії злочинності; розробити ефективні превентивні заходи.

При цьому кримінологія передбачає вивчення вже скоєних злочинів (зокрема, для характеристики особистості злочинця) та потенційних (гіпотетично можливих) злочинів (насамперед для профілактичної діяльності). Науковець також зазначає, що основними ознаками кримінологічного аспекту способу вчинення злочину є:

- спосіб вчинення злочину, який може охоплювати всі етапи злочинної діяльності, в тому числі й не виключаючи соціальну природу, що їі (злочинну діяльність) відображає, формування та виникнення умислу,

- оцінка способу вчинення злочину в кримінології, яка передбачає використання даних при реалізації всього комплексу заходів протидії злочинності: виявлення, припинення, розслідування, розкриття і запобігання злочинам [2, с. 146-147].
I.O. Морар звертає увагу на те, що традиційні для кримінології відомості, які обмежуються інформацією про особу злочинця і про його жертву, а також про певні типи кримінальних формувань, навряд чи здатні повністю надати попередженню наступальний характер. По суті, адепти кримінологічної науки без відомостей про спосіб вчинення злочинів позбавляють себе важливої інформації про «больові» точки цього соціального феномену [1, с. 79].

Цікавою в контексті кримінологічного вивчення способів вчинення злочину є думка К.В. Вишневецького щодо важливості дослідження особи жертви злочину і їі ролі в механізмі злочинної поведінки. Дослідник зазначає, що в межах віктимології розглядаються також питання загальної та індивідуальної превенції злочинів з точки зору віктимності потенційної жертви.

Особлива увага, за словами автора, звертається на роль віктимності у превенції латентної злочинності, адже одним із важливих бар'єрів у боротьбі зі злочинністю

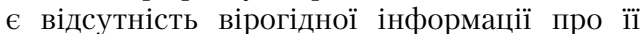
масштаби, наявність у їі структурі латентних злочинів [13, с. 208]. Схожою є точка зору Н.В. Генріх, яка зазначає, що у предмет кримінології як складовий елемент повинно ввійти і вчення про жертву злочину, адже без зв’язку діяння 3 віктимністю і поведінкою жертви важко розкрити механізм злочинної поведінки [14, с. 27].

Щодо детермінованості способів вчинення злочину М.I. Панов і Б. Щур зазначають, що детермінованість злочинної поведінки і способу вчинення злочину (як спеціальний вид детермінації) в науці кримінального права розглядається як складний, діалектично суперечливий процес, в якому зовнішні, об'єктивні обставини діють через внутрішні умови (свідомість і волю особи) і породжують відповідний акт вольової поведінки (діяння) не самі по собі, а лише у взаємодії з особистістю, заломлюючись крізь її інтереси, моральні уявлення, погляди та установки, особливості психіки та інші індивідуальні суб'єктивні властивості і якості [11, с. 544-545].

О.В. Дикий зазначає, що дослідження способу вчинення злочину у кримінологічній науці дозволяє виявити мотиви, цілі, життєві установки, потреби особи, яка скоює злочин, та інші явища, що дозволяють розкрити проблеми детермінації не тільки окремого злочину, а й окремого виду злочинності загалом, більш ефективно її попереджувати [15, с. 34]

Більшість науковців [11; 16; 17] погоджуються, що фактори, які детермінують спосіб вчинення злочину, можна класифікувати як: 
- об’єктивні елементи (час, місце i загальна обстановка вчинення злочину, об'єкт і предмет злочинного посягання, відносини між об'єктом злочинного зазіхання і злочинцем, технічна оснащеність злочинця, наявність співучасників тощо),

- суб'єктивні елементи (мета і мотив скоєння злочину, психічні властивості особистості злочинця, вміння, навички і звички злочинця, його стан тощо).

Дослідники [11; 16; 17] зазначають, що обставини об'єктивного і суб'єктивного характеру в їх діалектичній єдності, що детермінують той чи інший спосіб вчинення злочину, можуть перебувати в різних відносинах і зв'язках. Одні з них можуть переважати над іншими або перебувати у протидії (суперечності) між собою або ж бути в єдності і поєднанні. Але їх взаємодія здійснює визначальний вплив на особливості того чи іншого способу вчинення злочину, який внаслідок цього набуває специфічних, притаманних йому «індивідуальних» рис і властивостей, які відрізняють його від інших способів.

Визначення конкретних об'єктивних і суб'єктивних факторів, що детермінують спосіб вчинення злочину, можливе лише на основі здійснення кримінологічного дослідження способу вчинення тих чи інших груп злочинів. Чітке визначення детермінантів дозволить побачити, які обставини дійсно впливають на реалізацію злочинних наміpiв, а які є застарілими кліше, зрозуміти, як окремі криміногенні та некриміногенні фактори впливають на вибір способу вчинення злочину, оцінити, яким є співвідношення об'єктивних і суб'єктивних факторів у конкретному виді злочинності, виявити, які фактори є «новими» для наявних вчень про злочинність тощо.

Таким чином, науковці намагаються відповісти на питання «для чого необхідне кримінологічне вивчення способу вчинення злочину?», «якими можуть бути результати якісного кримінологічного дослідження способів вчинення злочинів?», «чи буде кримінологічне дослідження способів вчинення злочинів результативним і перспективним?» «чи можливо застосувати результати кримінологічного дослідження способу вчинення злочину на практиці?».

Вважаю, що такі дослідження є необхідними та перспективними. Їх результати дозволять не лише позбутися поверховості та «формальності» кримінологічних досліджень, а й створять можливість по-новому побачити сучасну злочинність, оцінити її масштаби та тенденції, виявити «нові» криміногенні фактори, вразливості та недоліки об'єктів кримінальних посягань.
Водночас кримінологічне дослідження способів вчинення злочинів матиме не лише науково-теоретичну цінність, а й практичну значущість, оскільки дозволить вдосконалити систему превентивних заходів і може стати складовою частиною навчання працівників правоохоронних органів. Крім того, якісне вивчення способів вчинення злочинів значно розширить можливості застосування кримінологічного моделювання, а також буде актуальним у плануванні та при формуванні кримінальної політики.

Для сучасного вивчення злочинності та для подальшого формування концепції кримінологічного дослідження способу вчинення злочину (наповнення іï змістом, визначення структури та категорійного апарату) ключовими, на мою думку, $є$ формування рекомендацій, розроблення методики та стратегії дослідження способів вчинення злочинів. Саме цим напрямам наукового дослідження будуть присвячені мої подальші праці.

\section{Висновки}

Все більше науковців-кримінологів погоджуються з тим, що сучасна кримінологія, їі предмет і фундаментальні концепції потребують реформування та вдосконалення. Наявні кримінологічні теорії не здатні повністю дослідити та пояснити соціальну дійсність, в якій існує людство нині, визначити сучасні криміногенні фактори та небезпечні для людини, суспільства і держави виклики, сформувати ефективні превентивні заходи та рекомендувати дієву політику протидії злочинності.

Одним із кримінологічних напрямів, що потребує якнайшвидшого дослідження та утвердження як окремого концептуального підходу, є спосіб вчинення злочину. Спосіб вчинення злочину є категорією, яка застосовується у кримінально-правових, криміналістичних дослідженнях та у кримінально-процесуальній теорії доказування.

Щодо кримінології, то вчення про спосіб вчинення злочину не є абсолютно новим для цієї науки, однак за останні 50 років цьому напряму не було приділено достатньої уваги. Всі наявні дослідження способу вчинення злочину $є$ поверхневими, несистемними та «фрагментарними», такими, що мають «формальний характер» і не заглиблюються в суть вивчення проблеми.

Вивчення способу вчинення злочину у кримінології дозволить заповнити наявні прогалини в загальній картині злочинності, переосмислити канонічні уявлення про той чи інший вид злочинності, оновити профіль особи злочинця, визначити ключові 
об'єктивні та суб'єктивні фактори, що детермінують спосіб вчинення злочину та механізм злочинної поведінки загалом. Крім того, якісне вивчення способів вчинення злочинів значно розширить можливості застосування кримінологічного моделювання, що дозволить виявляти недоліки та вразливості об'єктів злочинних посягань, а також буде актуальним у плануванні та при розробленні стратегій боротьби зі злочинністю

Наявні теоретичні напрацювання щодо способу вчинення злочину (у кримінологічному аспекті) мають важливе значення, незважаючи на те, що лише визначають перспективи та описують потенційні результати здійснення досліджень способу вчинення конкретних злочинів. Роботи науковців, яких було згадано у цій статті, є вихідними для формування окремих гіпотез і для подальшого вивчення способу вчинення злочину як окремого об'єкта кримінологічних досліджень. Крім того, актуальним є використання теоретичних і методологічних основ вивчення modus operandi при розробленні концептуальних положень кримінологічного дослідження способу вчинення злочину.

\section{Список використаних джерел:}

1. Морар I.О. К вопросу о способах совершения компьютерных преступлений. Вестник Московского университета МВД России. 2011 № 10. C. 78-79. URL: https://cyberleninka. $\mathrm{ru} /$ article/n/k-voprosu-o-sposobah-soversheniyakompyuternyh-prestupleniy.

2. Резюк В.И. Уголовно-правовой, криминалистический и криминологический аспекты способа совершения преступления: унификация и обособление. Проблемы укрепления законности и правопорядка: наука, практика, тенденции, 2017. № 10. C. 142-149. URL: https://elibrary.ru/item. asp?id $=37330694$.

3. Шиханцов Г.Г. Криминология. Минск, 2006. Веб-сайт. URL: http://ebooks.grsu.by/ criminal/predislovie.htm.

4. Самойлов А.В. Учение о механизме совершения преступления: история возникновения и развития // Ученые записки. Электронный научный журнал Курского государственного университета. 2010. № 3 (15). URL: https://cyberleninka.ru/article/n/uchenieo-mehanizme-soversheniya-prestupleniya-istoriyavozniknoveniya-i-razvitiya.

5. Stephen Hatton Criminal Modus Operandi and Psychoanalysis as Genealogical Evidence. URL: https://www.researchgate.net/ publication/315933223_Criminal_Modus Operandi_and_Psychoanalysis_as_Genealogical_ Evidence.

6. Бурлаков В.Н., Гилинский Я.И., Сморгунова А.Л., Шестаков Д.А. Зарубежная и российская криминология сегодня. Правоведение. 2000.
№ 4. C. 234-240. URL: http://www.law.edu.ru/ article/article.asp?articleID $=159616$.

7. Шиенок В.П. Очерки гуманистической методологии и национальной юриспруденции : монография. Минск : Междунар. ун-т «МИТСО», 2016. 238 c. URL: https://elib.bsu.by/ bitstream/123456789/181356/1/shienok monography.pdf.

8. Рыбак М.С. Связь уголовного права и криминологии как условие успешной борьбы с преступностью. Уголовно-правовой запрет и его эффективность в борьбе с современной преступностью. Сборник научных трудов. Саратов : Сателлит, 2008. C. 472-474. URL: http:// lawlibrary.ru/article2070880.html.

9. Номоконов В.А., Судакова Т.М. Криминология будущего - позитивная криминология? Lex Russica. Перспективы развития криминологии, 2018. № 9 (142). С. 29-38. URL: https:// cyberleninka.ru/article/n/kriminologiyabuduschego-pozitivnaya-kriminologiya.

10. Дрьомін B.M. Інституціональна теорія злочинності та криміналізації суспільства : автореф. дис. д-ра юрид. наук: 12.00 .08 «Кримінальне право; кримінологія i кримінально-виконавче право»; Нац. ун.-т «Одеська юридична академія». Одеса, 2010. 40 c. URL: http://dspace.onua.edu.ua/ handle $/ 11300 / 1410$

11. Панов Н., Щур Б. Об изучении способа совершения преступления в науках криминального цикла: междисциплинарный подход. Ежегодник украинского права, 2014 № 6. C. 537-552. URL: http://dspace.nlu.edu.ua bitstream/123456789/5520/1/Panov_SHyr_537.pdf.

12. Кримінологія: Загальна та Особлива частини : підручник / I.M. Даньшин, В.В. Голіна, М.Ю. Валуйська та інші; за заг. ред. В.В. Голіни. 2-ге вид., перероб. і доп. Харків : Право, 2009. 288 c. URL: http://library.nlu.edu.ua/POLN TEXT/KNIGI_2009/Kriminologia_2009.pdf.

13. Вишневецкий К.В. Место виктимологической теории в криминологии. Общество и право, 2010. № 1 (28). С. 208-212. URL: https://cyberleninka.ru/article/n/mestoviktimologicheskoy-teorii-v-kriminologii.

14. Генрих Н.В. Проблема предмета в современной криминологии. Теория науки. Виктимология, 2018. № 1 (15). C. 25-29. URL: https:// cyberleninka.ru/article/n/problema-predmeta-vsovremennoy-kriminologii.

15. Дикий О.В.Кримінологічна характеристика способів вчинення шахрайств у сфері обороту житлової нерухомості. Часопис Академії адвокатури України, 2014. Том 7. № 2 (23). С. 33-40. URL: http://nbuv.gov.ua/UJRN/Chaau_2014_7_2_5.

16. Колесниченко А.Н. Общие положения методики расследования отдельных видов преступлении / А.Н. Колесниченко. Харьков, 1976. 93 с.

17. Самойлов А.В. Понятие способа совершения преступления и его роль в системе механизма совершения преступления. Журнал научных публикаций аспирантов и докторантов. URL: http://www.jurnal.org/articles/2010/uri64.html. 
Mariana Fliunt. Theoretical and methodological fundamentals of studying the way of committing a crime in criminological science

The article is devoted to the study of theoretical and methodological fundamentals of studying the method of committing a crime in criminological science. It is stated that the method of committing a crime is an intersectoral category for the sciences of the criminal cycle, which is considered as part of the mechanism of criminal behavior or an element of the objective side of the crime.

At the same time, it is pointed out that of all the sciences of the criminal cycle, the method of committing a crime is the least studied in domestic criminology, as research on the method of committing a crime was carried out superficially and "fragmentarily" - usually as a dissertation delve into the essence of the method, its determination.

The paper identifies some problems and difficulties of criminological understanding of the concept of "crime", noted the possibility of applying in domestic criminology theoretical and methodological foundations of the study of "modus operandi', describes some prospects for research in this area and the development of criminological concept of crime.

It is emphasized that the refusal of a full criminological study of the method of crime leads to: the existence of significant gaps in the overall picture of crime and the profile of the offender, disregard for each type of crime objective and subjective determinants, the impossibility of forming an effective model of crime prevention and counteraction. In addition, the opinion was expressed that criminological research of the method of committing a crime will have not only scientific and theoretical value, but also practical significance, as it will identify shortcomings and vulnerabilities of objects of criminal encroachment, expand the application of criminological modeling, and be relevant in planning and formation of criminal policy of the state.

The author notes that the formation of recommendations, development of methods and strategies for researching ways of committing crimes are key areas for modern study of crime and for further formation of the concept of criminological research of ways of committing crimes, as well as its content, structure and categorical apparatus. His further research will be devoted to these areas.

Key words: criminal minds, criminal behavior, mechanism of committing a crime, modus operandi, determination of the way of committing a crime, criminological concept. 